\title{
Homework Assignment Preference Scale for Science Courses: A Validity and Reliability Study
}

\author{
İsa Deveci ${ }^{1, *} \&$ Nevzat Yiğit ${ }^{2}$ \\ ${ }^{1}$ Faculty of Education, Teacher Training School, Turku University, Turku, Finland \\ ${ }^{2}$ Fatih Faculty of Education, Department of Elementary Science Education, Karadeniz \\ Technical University, Sögütlü-Trabzon, Turkey \\ *Corresponding author: Visiting Researcher, Faculty of Education, Teacher Training School, \\ Turku University, Turku, Finland. E-mail: deveciisa@gmail.com
}

Received: December 12, 2014 Accepted: May 15, 2015 Published: May 29, 2015

doi:10.5296/ije.v7i2.6769 URL: http://dx.doi.org/10.5296/ije.v7i2.6769

\begin{abstract}
Homework assignments are have important role in learning process. In literature emphasizes that homework assignments do not attract students' attention and that students do homework assignment just for the sake of formality. It is concretely argued that assigned homework assignment should take into consideration students' preferences, interests, and needs. In this study, the "Homework Assignment Preference Scale" was developed to determine students' homework assignment preferences within the scope of a science course. A pilot study was conducted with 155 middle school students, and the main study was conducted with 924 middle school students. Exploratory factor analysis and principal components analysis were conducted to ensure the construct validity of the scale. Hierarchical cluster analysis and confirmatory factor analysis were performed to confirm the emergent factor structures. Results showed that the scale was a valid and reliable tool.
\end{abstract}

Keywords: science education, homework assignment preferences, validity and reliability, scale 


\section{Introduction}

Despite all the innovations and changes occurring in the educational process, homework assignments have always kept in their seat in curricula. In this sense, it is possible to say that homework assignment is important for all courses. Many educators employ homework assignment in the educational process from pre-school education to higher education. Homework assignment is defined as an extracurricular activity that reinforces the knowledge and skills acquired at school. It provides the opportunity to complete extra work on related subjects and to work as a group (McEwan, 1998; Papandreu, 1991; Türkoğlu, İflazoğlu, \& Karakuş, 2007). Homework assignment also provides students with opportunities to prepare for the next lesson, exercise their knowledge and skills about the subject that they have been learning, revise, conduct research using sources, make good use of their time, take responsibility, and think creatively and critically about a topic (Association of American Publishers, 1989; Amundson, 1999b; Aladağ, \& Doğu, 2009; Hong \& Milgram, 2000; Paulu \& Perkinson, 1995; Türkoğlu et al., 2007). Science subjects become more engaging when homework assignment involves cheap tools and materials that are easy to access at home and requires only the use of school facilities (Epstein, Jackson, \& Salinas, 1992). In consideration of the fact that the main purpose in science courses is to enable students to understand the scientific logic of daily events, it is possible to argue that homework assignment is one of the factors influential on success.

National studies in Turkey showed that homework assignment has an important positive impact on success in science (Büyüktokatl1, 2009; Hizmetçi, 2007; Kaplan, 2006; Kumandaş \& Kutlu, 2010; Özben, 2006). In an international study conducted by Uzun, Bütüner and Yiğit (2010) based on data provided by the Trends in International Mathematics and Science Study (TIMSS) for 1999 and 2007, Turkey was compared with the top five most successful countries (i.e., Taiwan, Singapore, Hungary, Japan, and South Korea) regarding the time students allocated for homework assignment in Science and Mathematics courses. According to this study, Turkish students fell behind those from Singapore but were more the time allocated for homework assignment than students from the other four countries. Another study based on the data provided by TIMMS from 1999 demonstrated that Turkish students allocated more time for out-of-school homework assignment when compared to students from other countries, yet Turkish students remained below average with regard to accuracy responding to science questions associated with everyday life (Özgün-Koca, \& Şen, 2002).

There were various national and international studies that do not cover Turkey. Postlethwaite and Wiley (1992) investigated the relationship between the time allocated for homework assignment and success in science among students from 23 countries. They found that students from countries where more time was allocated for homework assignment had higher success levels in science. There were many studies indicating that homework assignment has an important positive effect on the success of students in science (Van Voorhis, 2001; Cooper, Robinson \& Patall, 2006; Sabah \& Hammouri, 2010; Jones, 2007).

As mentioned in the literature on science homework assignment, it is evident that homework assignment practices in Turkey are somewhat problematic, as there may be differences in the 
homework assignment preferences of students or in the form of the homework assignment. Deveci (2011) found that, from the students' perspective, the frequency of homework assignment given in a science course was as follows (from more to less frequent): research, writing (summarizing), experimentation, and test questions. However, the frequency of homework assignment that students preferred in a science course was as follows (from more to less frequent): experimentation, research, interesting activities, test questions, observation, reading and writing activities, homework assignment related to nature and animals, and homework assignment related to everyday life. Kumandaş and Kutlu (2010) found that the determination of the subject of homework assignment by students affected the attitudes of the fifth grade students towards homework assignment. Gedik, Altıntaş and Kaya (2011) concluded that students enrolled in a science course wanted to be given preparatory homework assignment. Hong and Peterson (2002) showed that students preferred creative, comprehensive, preparatory, and applied homework assignment. Moreover, some of researchers have examined Turkish students' motivation sources, organisational approaches, physical needs and environmental and interpersonal preferences during the homework assignment process (İflazoğlu \& Hong, 2012a; 2012b). In this researh, Iflazoğlu and Hong (2012a; 2012b) used scale that is designed by Hong and Milgram (1998). In the scale developed by Tas, Sungur, and Oztekin (2014) was aim to determined middle-school (grades 6-8) students' perceptions of teachers' homework practices and homework self-regulation in science courses. Moreover, in the three scales designed by Deveci and Önder (2013b) was purpose to analyse opinions of students, teachers and parents regarding homework assignment given in science courses in terms of three factors (function, attitude and behavior). Thus, it is clear that students' preferences and requirements have not been taken into account when assigning homework assignment in science courses in Turkey. As mentioned in the literature on science homework assignment, there were studies with measurement tools that examine homework assignment from different perspectives. Although the majority of scale development studies focus on students' attitudes and opinions regarding homework assignment (Aladağ \& Doğu, 2009; Arı, 2010; Bedir, Polat \& Sakac1, 2009; Başboğaoğlu \& Demir, 2011; Gedik, Altıntaş \& Kaya, 2011; MetLife, 2007; Öcal, 2009; Yücel, 2004; Yeşilyurt, 2006; Yuladır \& Doğan, 2009), only a few have examined success (Hizmetçi, 2007; Kaplan, 2006; Özben, 2006; Van Voorhis, 2001). Some of researchers have take into account on the factors of family in homework assignment practices (Cooper, Lindsay, \& Nye 2000; Van Voorhis, 2001; Xu \& Corno, 2006). However, there is no measurement tool that accounts for the content of the homework assignment based on students' preferences in science courses.

Hong and Lee (2000) stated that the students' preferences were not taken into consideration in the primary education homework assignment process. In addition, Deveci and Önder (2013a) emphasized the differences among students' homework assignment preferences in science courses, and suggest taking into account such differences. In these context, the literature review shows that there are 3 types of homework assignment: 1) Exercising homework assignment that allow applying, repeating, and reinforcing the knowledge and skills learnt. 2) Preparatory homework assignment that aim for students to acquaint themselves with what they will learn in the next lesson; 3) Improvement homework 
assignment that aim to improve the imagination and creativity of students (Laconte, 1981; Doyle \& Barber, 1990; Department of Education, 2003; Türkoğlu et al., 2007). It is reported that the same type of homework assignment should not be given to students all the time, and students may have different homework assignment preferences especially for the science courses which are difficult to learn (Deveci \& Önder, 2013a). This is because; while some students may prefer improvement homework assignment depending on their knowledge and experiences, some other students may prefer preparatory homework assignment because they are not ready and are not knowledgeable enough. Therefore, it is deemed more rational to determine such preferences of students and give homework assignment in accordance with these preferences. Thus, there is a need for concrete material and a scale to guide teachers. This homework preference scale should allow the homework assignment process to have better results for both teachers and students. The current study aimed to develop a homework preference scale that measures students' homework assignment preferences within the scope of a science course.

\section{Methods}

Participants were selected through typical case sampling, which requires determining a typical case among many cases that exist in the universe in connection with the research problem and then acquiring data through this sample (Büyüköztürk et al., 2009). Typical case sampling allows for the formation of an opinion about a particular field by working on average cases (Yıldırım \& Şimşek, 1999). Since the present study aimed at working on the average student profile, the schools attended by the children of the families having an average income and socio-economic condition were preferred in accordance with the information obtained from teachers. The research sample consisted of 924 students attending three middle schools affiliated with the Ministry of National Education and located in the Akçaabat district of the Trabzon province (559) and Nilüfer district of the Bursa province (365) in Turkey. Sample consist of middle school students, because students have consciously began to do homework at the middle school age. The study was conducted during the 2011-2012 academic year. The sample size would be a minimum of five times the number of items included in the factor analysis procedure (but not less than 100 people) (Bryman and Cramer, 2001). According to Şencan (2005), a minimum of 100 people should be included provided that there are five participants for each variable, or a minimum of 10 participants should be included for each variable. Therefore, the number of participants in this study is sufficient. The distribution of students by gender and grade is provided in Table 1. The data obtained from 559 students were used in exploratory factor analysis and cluster analysis, while the data acquired from 365 students in another sample were used in confirmatory factor analysis. This study was limited to middle school science courses. In another limitation, for confirmatory factor analysis used the data collected form another city sample. And also, it is assumed that students give sincere answers. 
Table 1. Distribution of Students

\begin{tabular}{ccc}
\hline Variables & Category & Frequency \\
\hline \multirow{2}{*}{ Gender } & Girl & 494 \\
& Boy & 430 \\
\hline Total & & 924 \\
\hline \multirow{2}{*}{ Grade } & K6 & 326 \\
& K7 & 251 \\
Total & K8 & 347 \\
\hline
\end{tabular}

\subsection{The Development of the Data Collection Tool}

Forming items: During the scale's development phase, an item pool was created based on compositions written by 30 students and a group interview with five students regarding the type of homework assignment preferences that they prefer to have assigned in a science course. The written compositions and interviews were requested in order to determine what kinds of homework assignment preferences students wanted to be assigned in science courses. The homework assignment contents preferred by the students were revealed based on the feelings and thoughts of students in that matter (The preferred type of homework assignment) as well as the related literature. Then, a 47-item trial form was prepared. Some items included in the scale are provided below:

1. Homework assignment enabling us to question the events taking place in the nature should be given.

2. Homework assignment enabling us to observe the events taking place in the nature should be given.

3. Homework assignment enabling us to revise what we have learnt should be given.

4. Homework assignment enabling us to solve multiple-choice questions about what we have learnt should be given.

5. Homework assignment enabling us to use our hand skills related to the subject we will learn should be given.

6. Homework assignment enabling us to watch videos related to the subject we will learn should be given...

Scope / Content validity: Scope validity is defined as the extent to which items included in a measurement tool measure the relevant behaviors or characteristics (Balc1, 2010; Büyüköztürk, 2009). Whether the scale items properly measure the relevant characteristics can be determined based on expert opinions (Balc1, 2010; Büyüköztürk, 2009; Tavşancıl, 2010). Therefore, the 47-item trial form was evaluated by six faculty members specializing in "Science and Technology Education" and "Assessment \& Evaluation". Three unclear items were removed from the scale. In addition, the content validity ratio suggested by Lawshe 
(1975) was calculated so as to investigate the content validity of the scale. Lawshe states that the content validity ratio should not be less than .62 for each item when the number of experts is 5 to 10 . In the present study, content validity ratios varied between .86 and 1.00 . The final version of the trial form to be used in a pilot study consisted of 44 items.

Pilot study: A pilot study was conducted with 155 K6-8 grade students enrolled in three middle schools during the 2011-2012 academic year. Typically, pilot studies are conducted to eliminate considerable errors and examine scale items in more detail prior to the main implementation of a scale (Şencan, 2005). 6 items with item-total correlation and factor load values below .30 were removed from the scale. In addition, the researchers decided to remove an additional 6 items due to these items having low reliability coefficients or a high load value with more than one factor from the scale. A total of 11 items were removed from the scale during the pilot study. Thus, the final scale consisted of 32 items to be used the main study. The scale items were coded from positive to negative and scored from high to low (i.e., 5 [I strongly agree] 4321 [I strongly disagree]).

\subsection{The Administration of the Scale}

The scale was administered to 559 students by course teachers under the guidance of a researcher after the necessary information was provided to the participants. The scale took approximately 20 to 27 minutes to complete. The data obtained through the administration of this measurement tool were analyzed via a statistical package. The scale forms with deficiencies and errors were not included in the analysis.

\subsection{Data Analysis}

Reliability: Tavşancil (2010) and Baş (2008) define that reliable as a measurement tool's capacity to yield similar values at the end of repeated measurements. Cronbach's alpha coefficient provides information about the extent to which scale items measure a common structure (e.g., variable or factor) consistently (Özdamar, 2011; Şencan, 2005; Cronk, 2008). The reliability of the homework preference scale was investigated using Cronbach's alpha coefficient (i.e., internal consistency coefficient). The alpha value is strong when a single dimension is measured, whereas alpha coefficients may be low in multidimensional (i.e., multi-factor) scales. Therefore, the alpha coefficient should be calculated separately for each dimension as a sub-scale in multidimensional scales (Şencan, 2005). Cronbach's alpha coefficient was examined separately for each factor in the present study.

Validity: Validity is defined as the degree to which a measurement tool measures the relevant characteristic, which should be measured completely and correctly (Balc1, 2010; Tavşancıl, 2010; Şencan, 2005). Construct validity and scope validity were tested to reviewed the validity of the current scale. The opinions and recommendations of the six faculty members specialized in their fields were used to judge the scope validity of the scale. Construct validity refers to the degree to which a test measures the relevant behavior (e.g., factor or dimension) correctly (Tavşancıl, 2010; Balc1, 2010). A factor analysis was carried out to determine the construct validity of the scale. Factor analysis is a statistical procedure that has the function of finding new meaningful variables by bringing together a particular number of variables 
that are associated with one another (Büyüköztürk, 2009). To detect the construct validity of the homework preference scale, the data acquired from the scale were subjected to a hierarchical cluster analysis and a confirmatory factor analysis, as well as an exploratory factor analysis and a principal component analysis, to confirm the factors.

After removing the twelve items at the end of the pilot study, the 32-item measurement tool was administered to 559 students. The data acquired from 15 students who had deficiencies or marked more than one choice were excluded from evaluation.

\section{Results}

This section presents the findings that were obtained from the validity and reliability analyses.

\subsection{First Stage: An Evaluation of the Appropriateness of the Dataset for a Factor Analysis}

A Kaiser-Meyer-Olkin (KMO), a Bartlett Test of Sphericity, and an anti-image matrix were conducted to determine the appropriateness of the dataset for a factor analysis of the 32 item scale.

Kaiser-Meyer-Olkin (KMO): A KMO value over .60 refers to an adequate sample size (Büyüköztürk, 2009; Field, 2005). In this study from the main implementation, the KMO value was .93. Typically, a KMO value below .50 is unacceptable, a KMO value of .50 is weak, a KMO value of .60 is medium, a KMO value of .70 is acceptable, a KMO value of .80 is good, and a KMO value of .90 is very good (Tavşancıl, 2010).

Bartlett's Test of Sphericity: Bartlett's Test whether the data obtained from the sample display a normal distribution (Singh, 2007; Bryman \& Cramer, 2001). The significance of Bartlett's Test's result $(\mathrm{p}<.05)$ indicates that data are normally distributed (Field, 2005). In the present study, the Bartlett's Test of Sphericity had a significant result $(\mathrm{p}<.01)$.

Anti-Image Matrix: Anti-Image Matrix test the sampling adequacy of the items. If the values on the diagonal (i.e., cross value) $\left(\mathrm{x}^{\mathrm{a}}\right)$ are below 0.5 , the data are inadequate for a specific item. The values on the diagonal (i.e., cross value) should be over 0.5 (Field, 2005). In this study, these values were greater than .50 .

\subsection{Second Stage: An Evaluation of the Scale's Construct Validity}

To determine the scale's construct validity, the factor load value, item-total correlation, and overlapping status were examined.

Factor load: Büyüköztürk (2009) argues that factor load values of .45 or greater are good for selection. Bryman and Cramer (2001) state that items lower than .30 should be removed. Field (2005) suggests that factor load values for scale items should be over .30 or .40. Therefore, load values of .54 or greater were taken into consideration in this study. 
Item-total correlation: Büyüköztürk (2009) states that the item-total correlation should be at least .30, whereas Kayış (2009) suggests that it should be greater than .25. Therefore, I3 (item 3), I7, I6, I38, and I26, which were below .44, were removed from the scale to improve its validity. As evident in Table 1, item-correlation values were between .57 and .66 for the first factor, between .54 and .61 for the second factor, and between .44 and .53 for the third factor. Typically, items with item-total correlations of at least .30 have high levels of distinctiveness (Büyüköztürk, 2009).

Overlapping: Items related to more than one factor with a difference of less than .10 should be regarded as overlapping items and removed from the scale (Büyüköztürk, 2007). The removal procedure began with items that had the smallest differences. After each item was removed, the factor analysis was repeated, and I2, I4, I17, I19, I20, I21, I22, I20, I24, I25, I27, I30, I31, and I33 were removed from the scale. Table 2 presents the validity and reliability findings regarding the scale, with the final version consisting of 19 items.

\subsection{Third Stage: Obtaining Factors}

Eigenvalues, variance ratios, and a scree plot were established to determine the number of factors in the scale.

Eigenvalue: Eigenvalue refers to the amount of variance explained by the factors (Pallant, 2007; Singh, 2007). Eigenvalue is taken into account when deciding the number of factors (Büyüköztürk, 2009). Although some sources argue that variables with an eigenvalue above 1 should be taken into consideration (Thompson, 2002; Singh, 2007), others state that variables with an eigenvalue above than or equal to 1 should be considered (Miller, Acton, Fullerton, \& Maltby, 2002). In this study, three factors that had eigenvalues above 1 were considered. Table 2 shows that the eigenvalue belonging to the first factor is 7.34 , the eigenvalue belonging to the second factor is 1.58 , and the eigenvalue belonging to the third factor is 1.14 .

Variance ratio: The maximum number of factors is reached when the contribution of each factor to the percentage of explained total variance falls below 5\% (Eroğlu, 2009). The larger the variance ratio is, the stronger the factor structure is. A level of $30 \%$ or more is considered adequate for single-factor scales in social fields, whereas multi-factor scales are required to explain more of the variance (Büyüköztürk, 2009). A ratio between $40 \%$ and $60 \%$ is considered adequate for analyses conducted in social studies (cited by Tavşancil, 2002 from Scherer et al., 1988). Therefore, three factors with a contribution to the total variance that was greater than approximately $5 \%$ were taken into consideration, leading to a three-factor scale. Table 2 show that the variance explained by the first factor is $38.66 \%$, the variance explained by the second factor is $8.32 \%$, and the variance explained by the third factor is $6.0 \%$. The total variance attributed to the scale was $53 \%$ (Table 2 ).

Scree Plot: A scree plot is formed based on the eigenvalues of the factors. The vertical axis indicates the magnitude of an eigenvalue, whereas the horizontal axis presents the factors. The point where acceleration suddenly declines on the plot indicates the number of factors that should be considered (Singh, 2007). In other words, those factors that are observed until 
the point where the plot takes a horizontal shape are the number of factors that can be reached (Eroğlu, 2009).

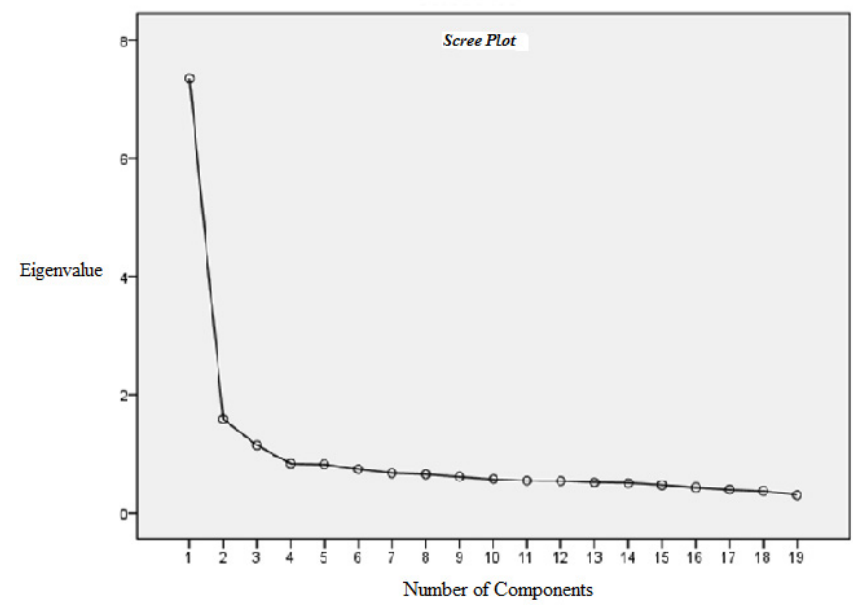

Figure 1. Scree Plot Showing the Number of Factors

Figure 1 shows that there is an accelerated sudden decline (e.g., the plot takes a horizontal shape) after factor 3 (i.e., factors 1,2, and 3 are in the section where the plot has a vertical shape). The plot takes on a horizontal appearance at component 4 . Thus, the scale has a three-factor structure.

\subsection{Fourth Stage: The Determination of the Variables}

Typically, after determining the number of factors, a rotation procedure is applied to interpret the factors (Pallant, 2007; Thompson, 2002; Eroğlu, 2009). There are two types of rotations, which are orthogonal and oblique. In the present study, the promax technique, which is an oblique rotation approach, was used based on the assumption that the factors were associated with each other. To make the analysis process clearer, pre-rotation and post-rotation factor loads, as well as item-total correlation values, related to each item are provided in Table 2. Table 2 shows that there are seven items associated with the first factor, and the rotated factor load values of these items varied between .59 and .82 . There are six items associated with the second factor, and the factor load values varied between .62 and .86. Finally, there are six items associated with the third factor, and the factor load values varied between .54 and .80

Based on analyses of the items with factor load values provided in Table 2, it is evident that the first factor consists of the items coded as "IF23, IF29, IF32, IF34, IF35, IF36, and IF37", the second factor consists of the items coded as "EF1, EF5, EF13, EF15, EF16, and EF28", and the third factor consists of the items coded as "PF8, PF9, PF10, PF11, PF12, and PF18". Here, IF23 refers to improvement factor 23rd item, EF1 refers to exercising factor 1st item, and PF8 refers to preparatory factor 8 th item. 
Table 2. Factor Load, Item-Total Correlation, and Cronbach's Alpha Values for the Scale Items

\begin{tabular}{|c|c|c|c|c|c|c|}
\hline \multirow{4}{*}{$\begin{array}{l}\text { Item } \\
\text { No }\end{array}$} & \multirow{4}{*}{$\begin{array}{l}\text { Pre-Rotation } \\
\text { Factor } \\
\text { Load Value }\end{array}$} & \multicolumn{3}{|c|}{ Rotated Factor Load Values } & \multirow{4}{*}{$\begin{array}{l}\text { Item-Total } \\
\text { Correlation } \\
\text { Values }\end{array}$} & \multirow{2}{*}{$\begin{array}{l}\text { Cronbach's } \\
\text { Alpha } \\
\text { Coefficient }\end{array}$} \\
\hline & & \multirow{3}{*}{ Factor 1} & \multirow{3}{*}{ Factor 2} & \multirow{3}{*}{ Factor 3} & & \\
\hline & & & & & & Upon Item \\
\hline & & & & & & Removal \\
\hline IF35 & .72 & .82 & & & .62 & .905 \\
\hline IF36 & .68 & .75 & & & .60 & .905 \\
\hline IF37 & .68 & .73 & & & .66 & .903 \\
\hline IF34 & .67 & .70 & & & .59 & .905 \\
\hline IF32 & .67 & .65 & & & .59 & .905 \\
\hline IF29 & .66 & .64 & & & .57 & .906 \\
\hline IF23 & .65 & .59 & & & .57 & .905 \\
\hline EF5 & .65 & \multicolumn{3}{|c|}{.86} & .54 & .906 \\
\hline EF3 & .63 & \multicolumn{3}{|c|}{.66} & .61 & .904 \\
\hline EF16 & .63 & \multicolumn{3}{|c|}{.66} & .55 & .906 \\
\hline EF15 & .62 & \multicolumn{3}{|c|}{.65} & .61 & .904 \\
\hline EF1 & .61 & \multicolumn{3}{|c|}{.64} & .61 & .904 \\
\hline EF28 & .60 & \multicolumn{3}{|c|}{.62} & .56 & .906 \\
\hline PF11 & .58 & & & .80 & .48 & .908 \\
\hline PF12 & .57 & & & .78 & .44 & .909 \\
\hline PF8 & .53 & & & .62 & .53 & .906 \\
\hline PF10 & .52 & & & .61 & .47 & .908 \\
\hline PF18 & .51 & & & .55 & .53 & .906 \\
\hline \multirow[t]{2}{*}{ PF9 } & .48 & & & .54 & .48 & .908 \\
\hline & & \multicolumn{2}{|c|}{ Factor 1} & Factor 2 & Factor 3 & The Entire Scale \\
\hline \multicolumn{2}{|c|}{ Eigenvalues } & \multicolumn{2}{|c|}{7.34} & 1.58 & 1.14 & 10.06 \\
\hline \multicolumn{2}{|c|}{ Explained Variance Ratios } & \multicolumn{2}{|c|}{38.66} & 8.32 & 6.00 & 53.01 \\
\hline \multicolumn{2}{|c|}{ Cronbach's Alpha } & \multicolumn{2}{|c|}{.85} & .83 & .78 & .91 \\
\hline
\end{tabular}

\subsection{Fifth Stage: Naming the Factors}

Table 2 presents the variables grouped according to the factors. The first factor was named "Improvement Homework Assignment" and consisted of responses in which students stated that they used their creative and critical thinking skills. The second factor was named "Exercising Homework Assignment" and consisted of responses in which students stated that they revised and reinforced their knowledge. The third factor was named "Preparatory Homework Assignment" and consisted of responses in which students stated that they prepared for the subjects that they would learn about in the following lesson. 


\subsection{Sixth Stage: Findings Related to the Reliability of the Scale}

The reliability coefficient $(\alpha)$ for the first factor of the scale was .85 , for the second factor of the scale was .83 , and for the third factor of the scale was .78 , according to the statistical findings about reliability (Table 2). The reliability coefficient for the entire scale was .91. All of these values are greater than .70, which is the high reliability for psychological tests (Büyüköztürk, 2009). Şencan (2005) argues that a coefficient greater than or equal to .70 is adequate for scientific studies, but that a minimum of .85 should be used for scales in studies involving interest and skill. According to Özdamar (2011), .70 $\leq \alpha<.90$ yields high reliability.

\subsection{Seventh Stage: The Correlations between the Factors}

There were positive significant correlations between the scale's factors (Table 3). The positive and significant nature of the correlations between the factors supports the argument that these components measure the same conceptual structure.

Table 3. The Correlations between the Scale's Factors

\begin{tabular}{llll}
\hline Factors & Improvement & Exercising & Preparatory \\
\hline Improvement & 1 & $.69^{* *}$ & $.56^{* *}$ \\
Exercising & $.763^{* *}$ & 1 & $.54^{* *}$ \\
Preparatory & $.56^{* *}$ & $.54^{* *}$ & 1 \\
\hline \multicolumn{2}{c}{$* *(\mathrm{p}<.01)$} & &
\end{tabular}

\subsection{Eighth Stage: The Confirmation of the Factors' Structures}

\subsubsection{Hierarchical Cluster Analysis}

Cluster analysis is defined as a series of methods developed to divide variables into sub-groups based on their characteristics (Alpar, 2011). The components that are similar to each other are brought together through cluster analysis. The clustering results obtained through Ward's method are compatible with exploratory factor analysis results; therefore, Ward's Method can be used as an alternative to exploratory factor analysis (Çokluk, Şekercioğlu, \& Büyüköztürk, 2010). In the present study, a the hierarchical cluster analysis technique was used to confirm the results obtained through the exploratory factor analysis. Moreover, hierarchical cluster analysis was used to strengthen the construct validity of the scale. Ward's technique, which is a hierarchical clustering method, was used in the cluster analysis. Pearson distance was used to determine the distance between the variables (Antalyal1, 2006). Items were grouped into 3 clusters at the end of the hierarchical cluster procedure, which is similar to the way that they were grouped into 3 factors in the exploratory factor analysis (Table 4). 
Table 4. Ward's Method Merger and Cluster Membership Results

\begin{tabular}{|c|c|c|c|c|c|c|c|c|}
\hline \multicolumn{7}{|c|}{ Ward's Method Merger } & \multicolumn{2}{|c|}{ Cluster Memberships } \\
\hline \multirow{4}{*}{ Stage } & \multicolumn{2}{|c|}{ Clusters Combined } & \multirow{4}{*}{ Coefficients } & \multicolumn{2}{|c|}{ Stage Cluster First } & \multirow{4}{*}{$\begin{array}{l}\text { Next } \\
\text { Stage }\end{array}$} & \multirow{4}{*}{ Items } & \multirow{4}{*}{$\begin{array}{l}\text { Three } \\
\text { Clusters }\end{array}$} \\
\hline & & & & \multicolumn{2}{|c|}{ Appears } & & & \\
\hline & \multirow{2}{*}{$\begin{array}{c}\text { Cluster } \\
1 \\
\end{array}$} & \multirow{2}{*}{$\begin{array}{c}\text { Cluster } \\
2\end{array}$} & & Cluster 1 & \multirow{2}{*}{ Cluster 2} & & & \\
\hline & & & & & & & & \\
\hline 1 & 17 & 19 & .29 & 0 & 0 & 5 & EF1 & 1 \\
\hline 2 & 2 & 8 & .56 & 0 & 0 & 7 & EF5 & 1 \\
\hline 3 & 6 & 7 & .82 & 0 & 0 & 16 & PF8 & 2 \\
\hline 4 & 9 & 10 & 1.08 & 0 & 0 & 10 & PF9 & 2 \\
\hline 5 & 17 & 18 & 1.33 & 1 & 0 & 6 & PF10 & 2 \\
\hline 6 & 16 & 17 & 1.56 & 0 & 5 & 11 & PF11 & 2 \\
\hline 7 & 1 & 2 & 1.79 & 0 & 2 & 14 & PF12 & 2 \\
\hline 8 & 12 & 15 & 2.02 & 0 & 0 & 13 & EF13 & 1 \\
\hline 9 & 3 & 11 & 2.24 & 0 & 0 & 12 & EF15 & 1 \\
\hline 10 & 9 & 13 & 2.45 & 4 & 0 & 14 & EF16 & 1 \\
\hline 11 & 14 & 16 & 2.66 & 0 & 6 & 13 & PF18 & 2 \\
\hline 12 & 3 & 5 & 2.84 & 9 & 0 & 15 & IF23 & 3 \\
\hline 13 & 12 & 14 & 3.01 & 8 & 11 & 17 & EF28 & 1 \\
\hline 14 & 1 & 9 & 3.16 & 7 & 10 & 17 & IF29 & 3 \\
\hline 15 & 3 & 4 & 3.32 & 12 & 0 & 16 & IF32 & 3 \\
\hline 16 & 3 & 6 & 3.44 & 15 & 3 & 18 & IF34 & 3 \\
\hline 17 & 1 & 12 & 3.40 & 14 & 13 & 18 & IF35 & 3 \\
\hline \multirow[t]{2}{*}{18} & 1 & 3 & 3.14 & 17 & 16 & 0 & IF36 & 3 \\
\hline & & & & & & & IF37 & 3 \\
\hline
\end{tabular}

In the first row of Table 4, there are 18 clusters for the 19-item scale. The second row below cluster 1 shows the first phase of the cluster analysis, which consists of 18 clusters. Based on the cluster memberships acquired via Ward's method, it is evident that the items EF1, EF5, EF13, EF15, EF16, and EF28 are in the first cluster, the PF8, PF9, PF10, PF11, PF12, and PF18 are in the second cluster, and the items IF23, IF29, IF32, IF34, IF35, IF36, and IF37 are in the third cluster. These findings are in parallel with the findings of the exploratory factor analysis, which are presented in Table 2 .

\subsubsection{Confirmatory Factor Analysis}

Confirmatory factor analysis was performed to confirm the three-factor structure that was obtained using the exploratory factor analysis. It is acceptable in scale development studies for confirmatory factor analysis to be conducted to confirm the factors that were determined through the exploratory factor analysis (Kline, 2010). The most important advantage when using a confirmatory factor analysis is that it can analyze latent variables free from measurement errors (Nachtigall, Kroehne, Funke, \& Steyer, 2003). Figure 2 and Table 5 


\section{Mll Macrothink}

International Journal of Education

ISSN 1948-5476

2015, Vol. 7, No. 2

present the results of the confirmatory factor analysis conducted on a different sample composed of 365 people.

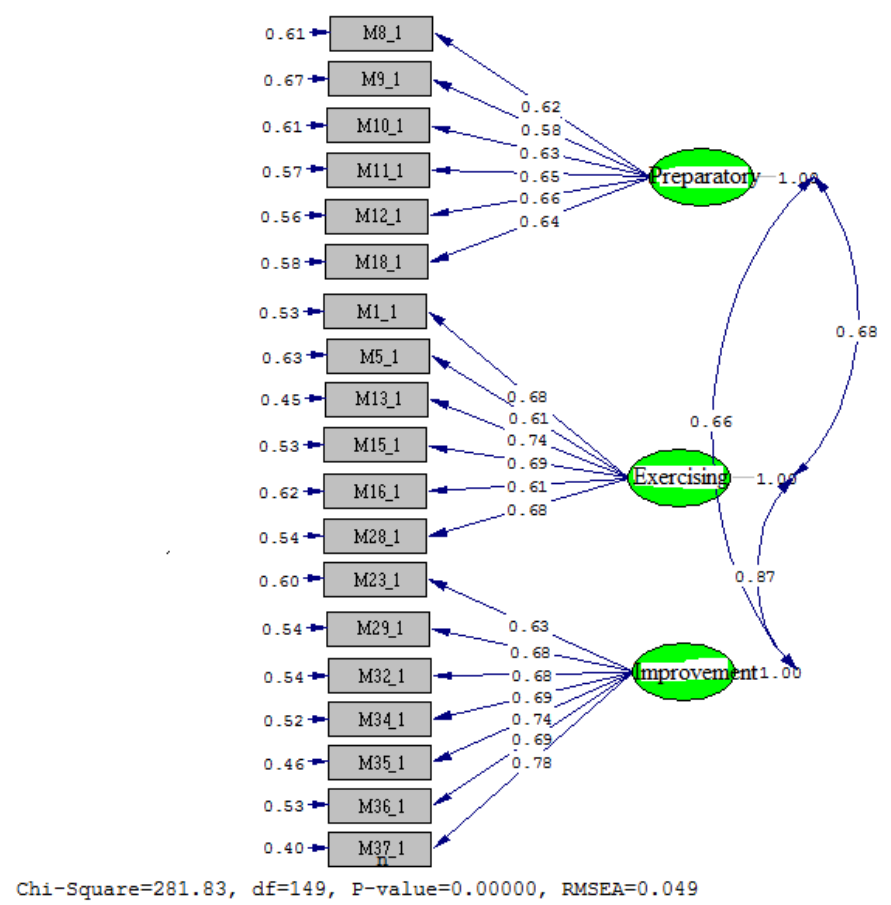

Figure 2. Standardized Analysis Values for the Results of the Confirmatory Factor Analysis on the Scale

Typically, there should not be significant differences between the expected and observed covariance matrices. The significant difference found here may be due to the size of the sample (Çokluk, Şekercioğlu, \& Büyüköztürk, 2010). The error variance for the indicators was examined and the highest value was .68 .

Table 5. The Fit Indices Calculated through The Confirmatory Factor Analysis

\begin{tabular}{llllllllll}
\hline Analysis & $\chi^{2}$ & \multirow{2}{*}{$\chi^{2} / \mathrm{df}$} & RMSEA & SRMR & GFI & AGFI & NFI & NNFI & CFI \\
\hline Values & 281.83 & 1.88 & 0.049 & 0.047 & 0.92 & 0.90 & 0.97 & 0.98 & 0.98 \\
\hline
\end{tabular}

$\chi^{2}=$ Chi-Square Goodness,,$\chi^{2} / \mathrm{df}=$ ratio of $\chi^{2}$ todf, RMSEA=Root Mean Square Error of Approximation, SRMR $=$

Standardized Root Mean Square Residuals, GFI = Goodness of Fit Index, AGFI = Adjusted Goodness of Fit Index, NFI= Normed Fit Index, NNFI = Nonnormed Fit Index, CFI= Comparative Fit Index.

The analysis results provided in Table 5 show that $\chi 2=281.83(\mathrm{sd}=149, \mathrm{p}>.01)$ and that the $\mathrm{Chi} / \mathrm{df}$ value is 1.88 . Typically, a value lower than 1 refers to a poor fit, whereas a value greater than 5 indicates the need to improve the model (Schumacker \& Lomax, 2004). The RMSEA value was .049. Values between 0 and .08 are considered to be indicators of a good 
fit (Hooper, Coughlan, \& Mullen, 2008), but .06 is considered the cut-off point (Hu \& Bentler, 1999). When this value is lower than 0.05, it is an indicator of a better fit (Şimşek, 2007; Fossati, Maffei, Acquarini, \& DiCeglie, 2003). The GFI value was .92, and the AGFI value was .90. Typically, the GFI and AGFI values are between 0 and 1, with 0 referring to no fit and 1 referring to an ideal fit (Schumacker \& Lomax, 2004). These values were not less than .90 (Hoyle, 2000; Hooper et al., 2008) in this study, there was a good fit. The SRMR value was .047. Typically, SRMR values lower than .05 indicate a good fit (Hooper et al., 2008), whereas values less than .08 imply an acceptable fit (Hu \& Bentler, 1999). When this value is assumed to be $\mathrm{x}, 0 \leq \mathrm{x} \leq .05$ is regarded as an indicator of a good fit (Schermelleh-Engel \& Moosbrugger, 2003). The NFI was .97, the NNFI was .98, and the CFI was .98. For these values, $.95 \leq \mathrm{x} \leq 1.00$ is considered an indicator of a perfect fit, whereas $.90 \leq \mathrm{x}<.95$ is accepted as an indicator of an acceptable fit (Hu \& Bentler, 1999; Sümer, 2000; Schermelleh-Engel \& Moosbrugger, 2003). Thus, the observed values were within the limits of a good fit. Therefore, the 3-factor structure of the 19-item the homework preference scale was confirmed as a model.

The student Homework Assignment Preferences Scale was finalized following the validity and reliability procedures. The final version of this scale consisted of 19 items (i.e., 7 for the first factor, 6 for the second factor, and 6 for the third factor) (ANNEX 1), as follows:

Improvement Homework Assignment: Items (23, 29, 32, 34, 35, 36, 37)

Exercising Homework Assignment: Items $(1,5,13,15,16,28)$

Preparatory Homework Assignment: Items $(8,9,10,11,12,18)$

\section{Discussion and Conclusions}

This study developed a novel scale to guide teachers in their homework assignment practices, such that the homework assignment serves an important function in the learning process, as students are given the opportunity to state their preferences. The scale items that were included to determine students' homework assignment preferences were grouped into fewer than three factors. Finally, the factor structures of the scale were confirmed through a cluster analysis and a confirmatory factor analysis.

Yücel (2004) designed a scale to examine the attitudes of secondary education students with regard to the homework assignment assigned in Chemistry courses and reported that the factor load values were greater than .45 , the reliability coefficient (Cronbach's alpha) was .91, and the amount of variance explained was 55\%. Batan (2007) developed a measurement tool to determine the factors affecting the homework assignment -related attitudes of fourth and seventh grade students and reported that the factor load value for the items was .30 as a criterion, the item-total correlations varied between .24 and .76, the amount of the variance explained was $38 \%$, and the reliability coefficient of the scale was .90 . In the study by Aladag and Doğu (2009) developed a 23-item scale to determine the opinions of second grade students regarding the homework assignment assigned in a science course and found that the 
reliability coefficient of the scale was 0.81 . They analyzed the responses of the participants with regard to frequency (f) and percentage (\%). In the study by Kumandaş and Kutlu (2010) developed a scale to examine the attitudes of fifth grade students regarding performance assignments and conducted validity and reliability analyses with the data collected from 325 students. They reported that the reliability coefficient of the scale was .96, the items gathered into two factors according to a factor analysis, the post-varimax rotation factor load values of the items for the first factor varied between .52 and .75, and the amount of the variance explained was $24.3 \%$. In the study by Öcal (2009) developed a homework assignment attitude scale to determine the attitudes of fourth and fifth grade students with regard to HA and reported that the reliability coefficient of the scale was .96 and that items with a factor load of .40 or greater were taken into consideration. In the study by Başboğaoğlu and Demir (2011) developed an attitude scale to determine teachers' views regarding the effectiveness of performance assignments for fourth and the fifth grade students and reported that the factor load values of the items varied between .55 and .75 , the amount of the variance explained was $66 \%$, and the reliability coefficient of the scale was .75. Thus, homework assignment -related scale development studies primarily yield validity and reliability results that parallel the results of the present study. However, the variance ratio explained in Kumandaş, and Kutlu's (2010) study was very low (24.3\%). An examination of homework assignment related scales with regard to disciplines and grades reveals that there are scales designed to investigate the attitudes of following groups: high school students regarding the homework assignment assigned in Biology (Yeşilyurt, 2006) and Chemistry (Yücel, 2004) courses, fourth to seventh grade students regarding their homework assignment (Batan, 2007), seventh grade students regarding performance assignments for a Social Studies course (Yücel, 2008), and fourth and fifth grade students regarding their homework assignment (Kumandaş \& Kutlu, 2010; Öcal, 2009; Özer \& Öcal, 2012). There are studies examining students' views of homework assignment through surveys consisting of open-ended questions (Corretjer, 2009; Gedik, Altıntaş \& Kaya, 2011). Moreover,

In the scale developed by Tas, Sungur, and Oztekin (2014) was aim to determined middle-school (grades 6-8) students' perceptions of teachers' homework practices and homework self-regulation in science courses. Moreover, in the three scales designed by Deveci and Önder (2013b) was purpose to analyse opinions of students, teachers and parents regarding homework assignment given in science courses in terms of three factors (function, attitude and behavior).Yet, previous literature does not show any use of a homework assignment preferences scale unique to science courses. There is one study examining the extent to which students agreed with scale items (i.e., percentage and frequency), but in this study Aladağ and Doğu, (2009) did not conduct statistical procedures with regard to scale development. Unlike previous studies in the literature, the present study focused on students' homework assignment preferences by going beyond the examination of students' attitudes toward homework assignment alone. Another novel feature of this study is that it is specific to a particular discipline.

Researchers have focused on developing single-factor attitude scales in the currently available homework assignment -related scales (Aladağ \& Doğu, 2009; Batan, 2007; Yücel, 
2004; Yeşilyurt, 2006). Across a number of studies, researchers have examined participants' responses to scale items with regard to percentages and frequencies after conducting reliability analyses of the scales regardless of the total score (Öcal, 2009; Özer \& Öcal, 2012; Yücel, 2008). In the multiple-factor scales are specific to science courses developed by some of the researchers have focused on other factors apart from the homework assignment preferences (Tas, Sungur, and Oztekin, 2014; Deveci and Önder, 2013b). Unlike the previously mentioned studies, the present study examined students' homework assignment preferences according to three factors (i.e., Improvement, Exercising, and Preparatory Homework Assignment). With this scale, the homework assignment preferences of students can be determined by calculating a total score for each factor. In this way, the homework assignment preferences of students may be taken into consideration according to their knowledge, skills, and readiness levels. For example, Deveci and Önder (2013a) concluded that students preferred different types of homework assignment in science courses. Moreover, Arslan (2013) emphasizes in the study conducted with Turkish teachers that teachers state that students' preferences should be taken into account in the homework assignment process. In this regard, it should be kept in mind that students may prefer any homework assignment type (i.e. preparatory, exercising, and improvement) based on their situations.In sum, this study emphasized that students' homework assignment preferences should be taken into account when deciding on homework assignment practices. In this respect, a scale was developed to determine students' homework assignment preferences in a science course.

\section{Implications}

The homework preference scale may be used as to determine the homework assignment preferences of students in a science course. By this means, while students may reach higher levels by doing preparatory homework assignment on the subjects in which they have deficiencies, those students who have a good grasp of subjects may improve their imagination and creativity through improvement homework assignment. Apart from that, the students with a medium grasp of subjects may reinforce their knowledge through practice exercises. In this process, teachers may determine what kinds of homework assignment their students prefer by using this concrete material in the beginning and at the end of a subject. Determining the homework assignment preferences of students, a teacher may assign the homework assignment type preferred by majority of the class or adopt a homework assignment policy unique to individuals in accordance with the class size. Additionally, it may be used as a source for scale development studies in different disciplines. A number of studies should be conducted with students from different grades and in different cities to investigate the validity and reliability of the scale. Moreover, scale development studies should be conducted based on different branches. In doing so, the views of students from different branches can be determined and homework assignment strategies can be developed based on these views. 


\section{References}

Aladağ, C., \& Doğu, S. (2009). Fen ve Teknoloji Dersinde Verilen Ödevlerin Öğrenci Görüşlerine Göre Değerlendirilmesi. Selçuk Üniversitesi Sosyal Bilimler Enstitüsü Dergisi, 21, 15-23.

Alpar, R. (2011). Uygulamalı Çok Değişkenli İstatistiksel Yöntemler. Detay Yayıncılık. Ankara.

Amundson, K. J. (1999b). Helping Your Child With Homework. Parents as Partners Series. American Association Of School Administrators, Arlington, (ERİC=ED436295).

Antalyalı, Ö. L. (2006). Kümeleme analizi (SPSS Uygulamalı Çok Değişkenli İstatistik Teknikleri) Ed. Şeref Kalaycı, (2. Baskı) Asil yayın dağıtım. Ankara.

Arı, A. (2010). Öğretmenlere Göre Proje ve Performans Görevlerinin Uygulanmasında Karşılaş1lan Sorunlar. Elektronik Sosyal Bilimler Dergisi, 9(34), 032-055.

Arslan, A. (2013). Türkçe Öğretmenlerinin Proje ve Performans Ödevleri ile İlgili Görüşlerinin Değerlendirilmesi. Journal of Language and Literature, 2(6), 11-22.

Association of Amerikan Publisher, (1989). Helping Your Child Succeed in School. New York, (ERİC, ED350077).

Balcı, A. (2010). Sosyal Bilimlerde Araştırma Yöntem, Teknik ve İlkeler (Sekizinci Baskı), Pegem Yayınc1lık, Ankara.

Baş, T. (2008). Anket, Anket Nasıl Hazırlanır, Uygulanır, Değerlendirilir ? (Beşinci Baskı), Seçkin Yayıncılık, Ankara.

Başboğaoğlu, U., \& Demir, M. (2011). İlköğretimde Uygulanan Performans Görevlerinin Etkililiğine İlişkin Geliştirilen Tutum Ölçeğinin Geçerlilik ve Güvenirlik Çalışması. Pegem Ĕ̈itim ve Öğretim Dergisi, 1(1).

Batan, B. (2007). İlköğretim Öğrencilerinin Ev Ödevleri İle İlişkili Tutumlarını Etkileyen Faktörler. Yüksek Lisans Tezi, Ankara Üniversitesi Eğitim Bilimleri Enstitüsü, Ankara.

Bedir, A., Polat, M., \& Sakac1, T. (2009). İlköğretim Fen ve Teknoloji Dersine Ait Bir Uygulama Çalışması: Portfolyo. C.B.Ü. Fen Bilimleri Dergisi, 5(1), 1-4.

Bryman, A., \& Cramer, D. (2001). Quantitative Data Analysis With SPSS Release 10 For Windows. Routledge is an imprint of the Taylor and Francis Group, USA and Canada. http://dx.doi.org/ 10.4324/9780203471548

Büyüköztürk, Ş. (2009). Sosyal Bilimler İçin Veri Analiz El Kitabı (10. Baskı), PegemA Yayıncilik. Ankara.

Büyüktokatl1, N. (2009). İlköğretimde Ev Ödevi Uygulamalarına İlişkin Öğretmen Görüşlerinin İncelenmesi. Yüksek Lisans Tezi, Selçuk Üniversitesi Sosyal Bilimler Enstitüsü, Konya. 
Çokluk, Ö., Şekercioğlu, G., \& Büyüköztürk, Ş. (2010). Sosyal bilimler için çok değişkenli istatistik: SPSS ve Lisrel uygulamaları. Pegem Akademi, Ankara.

Cooper, H., Lindsay, J. J., \& Nye, B. (2000). How student, family and parenting style differences relate to the homework process. Contemporary Educational Psychology, 25(4), 64-87. http://dx.doi.org/10.1006/ceps.1999.1036

Cooper, H., Robınson, C. J., \& Patall, A. E. (2006). Does Homework Improve Academic Achievement? A Synthesis of Research 1987-2003. American Educational Research Association, 76(1), 1-62. http://dx.doi.org/10.3102/00346543076001001

Corretjer, G. L. (2009). Listen ToMe ! An Exploration of the Students Voices Regarding Homework. Walden University, College Of Education.

Cronk, B. C. (2008). How ToUse SPSS A Step-by-Step Guide to Analysis and Interpretotion. Fifth Edition, Pyrczak Publishing, Printedin the United State of America Malloy, Inc.

Department of Education, (2003). Homework Tips For Parents=Consejos Para Los Padres Sobre La Tarea Escola, Washington, DC. Office of Intergovermental and Interagency Affairs, (ERIC, ED477945).

Deveci, İ. (2011). Fen ve Teknoloji Dersi Kapsamında İlköğretim Yedinci ve Sekizinci Sınıflarda Verilen Ödevler Hakkında Öğrenci, Öğretmen ve Veli Görüşleri, Yüksek Lisans Tezi, Eğitim Bilimleri Enstitüsü Sakarya Üniversitesi, Sakarya.

Deveci, İ., \& Önder, İ. (2013a). The Students' Views Related to the Given Homeworks in The Science and Technology Courses: A Qualitative Study, US-China. Education Review, 3(1), 1-9.

Deveci, İ., \& Önder, İ. (2013b). Fen ve Teknoloji Derslerinde Verilen Ödevlere Yönelik Öğretmen, Öğrenci ve Veli Ölçeklerini Geliştirme Çalışması. Journal of Turkish Science Education, 10(3), 159-184.

Doyle, M. A. E., \& Barber, B. S. (1990). Homework as a Learning Experience. What Research Says to the Teacher. (ERIC, ED319492).

Epstein, J. L., Jackson, V. E., \& Salinas, K. C. (1992). TIPS, TeacherİnvolveParent İn Schoolwork Language Arts And Science/Health. İnteractive Homework İn TheMiddle Grade. Manual For Teachers. Center On Families, Communities, Schools And Childrens Learning, The Jhons Hopkins Üniversity, 3505 North Charles Street Baltimore, Maryland 21218.

Eroğlu, A. (2009). SPSS Uygulamalı Çok Değişkenli İstatistiksel Teknikler, Şeref Kalaycı (Ed.), Faktör Analizi (4. Baskı), Asil yayıncılık, Ankara.

Field, A. (2005). Discovering statisticsusing SPSS (2nd ed.). Sage Yayınları, London.

Fossati, A., Maffei, C., Acquarini, E., \& Di Ceglie, A. (2003). Multigroup confirmatory component and factor analyses of the Italian version of the aggression questionnaire. European Journal of Psychological Assessment, 19(1), 54-65. http://dx.doi.org/ 
$10.1027 / / 1015-5759.19 .1 .54$

Gedik, N., Altıntaş, E., \& Kaya, H. (2011). Fen ve Teknoloji Dersinde Verilen Ev Ödevleri Hakkında Öğrenci Görüşleri. Journal of European Education, 1(1), 6-13.

Hizmetçi, S. (2007). İlköğretim 5. Sınıf Öğrencilerinin Ödev Stilleri İle Akademik Başarı Arasındaki İlişkinin İncelenmesi, Yüksek Lisans Tezi, Çukurova Üniversitesi Sosyal Bilimler Enstitüsü, Adana.

Hong E., \& Milgram, R. M. (2000). Homework : motivation and learning preference. An imprint of Greenwood Publishing Group, Westport, Connecticut, London.

Hong, E., \& Lee, K. (2000). Preferred homework style and homework environment in high-versus low achieving Chinese students. Educational Psychology, 20(2), 125-137. http://dx.doi.org/ 10.1080/713663718

Hong, E., \& Milgram, R. M. (1998). Homework motivation and preference questionnaire. University of Nevada, College of Education, Las Vegas, and Tel Aviv University, School of Education, Israel.

Hong, E., \& Peterson, J. (2002). Kinds of homework students prefer: comparisons between students who are andare not highly interested and active in science, social leadership, and literature. American Educational Reresearch Association, 1, 1-29.

Hooper, D., Coughlan, J., \& Mullen, M. (2008). Structural equation modelling: Guidelines for determining model fit. Electronic Journal of Business Research Methods, 6(1), 53-60.

Hoyle, R. H. (2000). Confirmatory factor analysis. In H. E. A. Tinsley and S. D. Brown (Eds.), Handbook of applied multivariate statistics and mathematical modeling (pp.465-497). New York: Academic Press. http://dx.doi.org/10.1080/02671522.2010.529581

Hu, L. T., \& Bentler, P. M. (1999). Cutoff criteria for fit indexes in covariance structure analysis: Conventional criteria versus new alternatives. Structural Equation Modeling, 6(1), 1-55. http://dx.doi.org/10.1080/10705519909540118

İflazoğlu, A., \& Hong, E. (2012a). Relationships of homework motivation and preferences to homework achievement and attitudes in Turkish students. Journal of Research in Childhood Education, 26(1), 57-72. http://dx.doi.org/10.1080/02568543.2011.632066

Iflazoglu, A., \& Hong, E. (2012b). Homework motivation and preferences of Turkish students. Research Papers in Education, 27(3), 343-363.

Jones, J. (2007). The Purpose of Homework and Its Relationship To Student Achievement, Action Research Project.

Kaplan, B. (2006). İlköğretim 6. Sınıf “'Yaşamımızı Yönlendiren Elektrik“ Ünitesinde Ev Ödevi Verilmesinin Öğrenci Başarısına ve Kavram Öğrenmeye Etkisi. Yayınlanmış Yüksek Lisans Tezi, Marmara Üniversitesi Eğitim Bilimleri Enstitüsü, İstanbul. 
Kayış, A. (2009). SPSS Uygulamalı Çok Değişkenli İstatistiksel Teknikler, Şeref Kalaycı (Ed.), Güvenirlik Analizi, (4. Baskı), Asil yayıncılık, Ankara.

Kline, R. B. (2010). Principles and practice of structural equation modeling (3rd ed.). New York: Guilford Press.

Kumandaş, H., \& Kutlu, Ö. (2010). İlköğretim 5. Sınıf Öğrencilerinin Performans Görevlerine İlişkin Tutumlarını Etkileyen Faktörler. İlköğretim Online Dergisi, 9(2), 714-722.

Laconte, T. R. (1981). Homework as a Learning Experiance, What Research Says to the Teacher, (ERİC, ED217022).

Lawshe, C. H. (1975). A quantitative approach to content validity. Personnel Psychology, 28, 563-575. http://dx.doi.org/ 10.1111/j.1744-6570.1975.tb01393.x

Mcewan, E. K. (1998). Anababalara Pratik Öneriler. Şerife Küçükal (Çeviri), Hyb Yayıncılık, Ankara, Çeviri Y1lı: 2010.

MetLife. (2007). A Survey Of Students, Teachers and Parents, MetLife, The Homework Experiance, The Metlife Survey Of The American Teacher.

Miller, R. L, Acton, C., Fullerton D. A., \& Maltby, J. (2002). SPSS for Social Scientists. Consultant editor: Jo Campling, İmprint of The Palgrave Macmillan, New York.

Nachtigall, C., Kroehne, U., Funga, F., \& Steyer, R. (2003). Should we use SEM? Structural equation Modeling. Methods of Psychological Research Online, 8(2), 1-22.

Öcal, S. (2009). İlköğretim 4. ve 5. Sınıf Öğrencilerinin Ev Ödevlerine Yönelik Tutumlarının Oluşmasında Ailelerin ve Öğretmenlerin Rolü. Yüksek Lisans Tezi, Mustafa Kemal Üniversitesi Eğitim Bilimleri Enstitüsü, Hatay.

Özben, B. (2006). İlköğretim İkinci Kademe Öğrencilerinin Fen Bilgisi Dersindeki Başarılarına Ev Ödevi Çalışmalarının Etkisi. Yayınlanmış Yüksek Lisans Tezi, Eğitim Bilimleri Enstitüsü Gazi Üniversitesi, Ankara.

Özdamar, K. (2011). Paket Programlar İle İstatistiksel Veri Analizi (8. Bask1), Kaan Kitapevi, Eskişehir.

Özer, B., \& Öcal, S. (2012). İlköğretim 4. Ve 5. Sınıf Öğrencilerinin Ev Ödevlerine Yönelik Tutumlarının Değerlendirilmesi, Dicle Üniversitesi Ziya Gökalp Eğitim Fakültesi Dergisi, 18, 1-16.

Özgün-Koca S. A., \& Şen, A. İ. (2002). 3. Uluslar arası Matematik ve Fen Bilgisi Çalışması Tekrar Sonuçlarının Türkiye için Değerlendirilmesi, Hacettepe Üniversitesi Eğitim Fakültesi Dergisi, 23, 145-254.

Pallant, J. (2007). Survival Manual, A Step by Step Guide to Data Analysis using SPSS for Windows(3rd Edition.). Open University Press, New York.

Papandreu, A. (1991). Homework in Teaching and Learning, Report, (ERİC, ED352811). 
Paulu, N., \& Perkinson, K. (1995). Helping Your Child With Homework, Washington, D.C., U.S., Departmen of Education.

Postlethwaite, T. N., \& Wiley, D. E. (1992). The IEA Study of Science 11: Science Achievement in Twenty-Three Countries. Oxford: Pergamon.

Sabah, S., \& Hammouri, H. (2010). Does subject matter? Estimating the impact of instruction alpractices and resources on student achievement in science and mathematics: findings from TIMSS 2007. Evaluation and Research in Education, 23(4), 287-299. http://dx.doi.org/ 10.1080/09500790.2010.509782

Schermelleh-Engel, K., \& Moosbruger, H. (2003). Models: Tests Of Significance And Descriptive. Methods of Psychological Research Online, 8(2), 23-74.

Schumacker, R.E., \& Lomax, R.G. (2004). A Beginner's Guide To Structural Equation Modeling (2nd Edition). Lawrence Erlbaum Associates Publishers, Londra, 79-122.

Şencan, H. (2005). Sosyal ve Davranışsal Ölçümlerde Güvenirlik ve Geçerlilik. Seçkin Yayınc1lık, Ankara

Şimşek, Ö. F. (2007). Yapısal eşitlik modellemesine giriş, temel ilkeler ve LISREL uygulamaları. Ankara: Ekinoks Eğitim ve Danışmanlık Hizmetleri, Siyasal Basın ve Dağıtım.

Singh, K. (2007). Quantitative Social Research Methods. Sage Publications, Los Angeles.

Sümer, N. (2000). Yapısal eşitlik modelleri: Temel kavramlar ve örnek uygulamalar. Türk Psikoloji Yazılarl, 3(6), 49-74.

Tas, Y., Sungur, S., \& Oztekin, C. (2014). Development and valıdation of science homework scale for middle-school students. International Journal of Science and Mathematics Education, 1-28. http://dx.doi.org/ 10.1007/s10763-014-9582-5

Tavşancıl, E. (2010). Tutumların Ölçülmesi ve SPSS ile Veri Analizi (Dördüncü Baskı), Nobel Yayıncılık, Ankara.

Tezbaşaran, A. A. (1997). Likert Tipi Ölçek Geliştirme Kılavuzu, Türk Psikologlar Derneği Yayınları, Ankara.

Thompson, B. (2002). Exploratory and confirmatory factor analysis: understanding concepts and applications, Data Reproductions, American Psychological Association, Washington.

Türkoğlu, A., İflazoğlu, A., \& Karakuş. M. (2007). İlköğretimde Ödev, Morpa Kültür Yayınları, İstanbul.

Uzun, S., Bütüner Ö. S., \& Yiğit. N. (2010). 1999-2007 TIMSS Fen Bilimleri ve Matematik Sonuçlarının Karşılaştırılması: Sınavda En Başarılı İlk Beş Ülke-Türkiye Örneği, Elementary Education Online, 9(3), 1174-1188.

Van Voorhis, F.L. (2001). Teachers' Use of Interactive Homework and Its Effects on Family 
Involvement and Science Achievement of Middle Grade Students. Washington DC, (ERIC ED454049).

Xu, J., \& Corno. L. (2006). Gender, Family Help, and Homework Management Reported by Rural Middle School Students. Journal of Research in Rural Education, 21(2), 1-13.

Yeşilyurt, S. (2006). Lise Öğrencilerinin Biyoloji derslerinde Verilen Ev Ödevlerine karşı Tutumları Üzerine Bir Çalışma. Erzincan Ĕ̆itim Fakültesi Dergisi, 8(1), 37-53.

Yıldırım, A., \& Şimşek, H. (1999). Sosyal Bilimlerde Nitel Araştırma Teknikleri. Seçkin Yayınevi. Ankara.

Yücel, A. (2008). İlköğretim 7. Sınıf Sosyal Bilgiler Dersi'inde Verilen Preformans Ödevleri Hakkında Öğretmen - Veli - Öğrenci Görüşleri. Yüksek Lisans Tezi, Selçuk Üniversitesi Sosyal Bilimler Enstitüsü, Konya.

Yücel, A. S. (2004). Ortaöğretim Düzeyindeki Öğrencilerin Kimya Derslerinde Verilen Ev Ödevlerine Karşı Tutumlarının İncelenmesi. Gazi Eğitim Fakültesi Dergisi, 1(24), 147-159.

Yuladır, C., \& Doğan, S. (2009). Fen ve Teknoloji Dersinde Öğrencilerin Ev Ödevi Performansını Arttırmaya Yönelik Bir Eylem Araştırması. Çankaya Üniversitesi Fen-Edebiyat Fakültesi. Journal of Artsand Sciences, 12, 211-238.

\section{Copyright Disclaimer}

Copyright for this article is retained by the author(s), with first publication rights granted to the journal.

This is an open-access article distributed under the terms and conditions of the Creative Commons Attribution license (http://creativecommons.org/licenses/by/3.0/). 